\title{
EGEMEN KÜRESEL HEGEMONYADA NEOLIBERALIST VE POSTMODERN KÜLTÜR: COCA COLA REKLAMLARINDA RAMAZAN
}

\author{
Mehmet Barış YILMAZ ${ }^{1}$ \\ Mehmet BABACAN ${ }^{2}$
}

\section{Özet}

Bu çalışmada günümüzde önemli bir yere sahip olan, görsel işitsel medya aracı televizyonda ve internet ortamında son yıllarda yaygınlaşan reklam okyanusunda yer alan ve geniş kitlelere hitap eden 'Coca Cola Reklamlarında Ramazan" konusu ele alınarak izleyiciler tarafından nasıl alımlandığını ortaya koymak amaçlanmaktadır. Bu reklamların hedef kitle üzerindeki egemen yaklaşımı incelenmektedir. Çalışma da niteliksel araştırma yöntemi alımlama analizi tekniği kullanılmıştır. Farklı sosyo-demografik özelliklere sahip 8 kişi ile yapılan görüşmeler gözlem tekniği ile de desteklenerek gerçekleştirilen çalışmada izleyici yorumları mercek altına alınmıştır. Çalışmada, izleyicilerin iletilere karşı oldukça duyarlı olduğu tespit edilmiştir. Sosyo-demografik ve kültürel değişkenlerin sunulan içeriğe yönelik direnç açısından farklılık gösterdiği elde edilen bulgular arasındadır. Küresel bir markanın yerel dinamik ve değerler ile kitle iletişim araçları üzerinden nasıl yoğunlaştığı ve özdeşleşmede güçlendiği tespit edilmiştir.

Anahtar Kelimeler: Neoliberalizm, Postmodernite, Alımlama, Egemen Kültür, Hegemonya 


\section{Giriş}

Tarihsel noktadan incelenen izleyici temelli çalışmalarda, eleştirel ce egemen olarak iki farklı değerler silsilesinden bahsedilebilir. Seyircinin aktif olduğu görüşünde olan gerçekçi vasfa sahip Kullanımlar ve Doyumlar Yaklaşımı, hedef kitleyi sadece verilen iletilerin ulaştığı kişiler olarak sınırlamaz. Bu kuram, özellikle televizyon iletilerinin niçin ve ne yönden iletildiği sorusuna yanıt vermeye çalışır. Hedef kitlenin medyayı kullanım amaçlarından öte kitle iletişim araçlarından sağladığı tatmin yani beklentilerin giderilmesi de kuramın yanıt aradığ mel sorudur. Eleştirel yaklaşımın çerçevesinde var olan izleyici odaklı alımlama çalışmaları bireylerin medya karşısında aktif bir noktada da bulunduğunu öne sürmektedir. Stuart Hall ortaya koyduğu ve geliştirdiği Kodlama ve Kodaçımlama Modeli'nden meydana gelen alımlama analizine göre bireyler kitle iletişim araçlarına ilişkin çeşitli anlamlar geliştirirler. Yani verilen metin ve görsellerin tek düze alımlanması mümkün değildir. Kitle iletişim araçları içerikleri üç kilit nokta da alımlanır; müzakereci okuma, muhalif okuma ve hâkim okumadır. Hâkim okuma hegemonik ideolojiyi niteler konumdayken, muhalif okuma hegemonik noktaları ortaya çıkarır ve karşı çıkar, müzakereci okuma ise temel kodların desteklendiği, belirli kodlara ise karşı çıkıldığı okumadir (Hall 2003: 321).

İzleyici temelli araştırmaların en taze gelişmelerden biri de Alımlama Analizidir. Alımlama analizinde ilk zamanlarda haber metinleri konusunda çalışmalar yürütülürken, ilerleyen dönemlerde bu araştırmalar TV metinlerine kaymıştır. Bu analiz tekniği, ileti-izleyici ilişkisi noktasında nitel ve görgül temelli bir analiz sunmaktadır. Bununla birlikte alımlama çözümlemesiyle ilgili durumlar değerlendirilebilir ve TV metinleri iletilmesi ve etkileri noktasında çözümler geliştirilebilir (Hall 2003: 321).

Günümüzde küreselleşmeyle kültürün, küresel medya kurumları tarafından medya metin ve görselleri aracılığıyla bütün dünyaya gönderildiği görülebilir. Jest, mimik ve söylemler ile gönderilen bu mesajların farklı analmalandırmalar ortaya koyduğu ve bireylerin paylaşımda 
bulunduğu bu anlamlandırmaların ise dil yardımıyla şekillendirildiği ve gönderildiğinden bahsedilebilir. Tüm bu anlamların işitsel ve görsel olarak karakterize edilerek oluşturulduğu ve hedef kitleye gönderildiği temel argümanlardan birisi televizyondur. İzleyicileri temel alan bu analizler de bu anlamlar nasıl inşa edilir, yani kodlanır ve izleyiciler tarafından nasıl anlamlandırılır yani kodaçımı yapılabilir? Sorularının yanıtına cevap bulunulmaya çalışıldığından kodlama ve kodaçımı basamakları ve bu süreç üzerine çalışılmasında hedef kitleye aktif noktada odaklanan Alımlama Analizi tekniğinin üzerine düşünülmesi gerektiği ifade edilmektedir (Yücel 2010: 8).

Türkiye’ de özellikle son yirmi yılda bireysel, kültürel, değersel ve siyasal açıdan temel değişiklikler ve kapsamlı dönüşümler gerçekleşmektedir. Bu dönüşümlerin oluşturduğu belirsiz ortamda, medya materyallerinden en fazla kullanılanı ve maddi olarak uygun olanı televizyon, kültürel dönüşümlerin taşıyıcısı konumunda bulunmaktadır (Demir 2008: 3).

Bilginin dağıtılmasında kilit öneme sahip kitle iletişim araçları, tüketim kültürünün oluşmasında da, birey ile sistem arasında "köprü" görevi görmektedir. Televizyon vasıtası ile hayat pratikleri, düşünme biçimleri, tüketim kültürleri bireylere aşılanmaktadır. Fakat küçük kentlerde yeni tüketim pratikleri ile geleneksel yapı arasında net farklılıklara ortaya çıkmaktadır (Demir 2008: 3).

II. Dünya Savaşı sonrasında televizyon yaygınlık kazanmaya başlamış ve bununla birlikte reklamcılık faaliyetlerinin etkilediği alanlar genişlemiş ve bu ayrıntı da reklâmların görünür veya görünmez propaganda için fazlasıly önemli bir metot haline bürünmesine sebebiyet vermektedir (Şeker 2011: 3).

Reklamlar büyük markaların satış amacını gerçekleştirmek için olmazsa olmaz bir öneme sahiptir. Küresel markalar reklamları oluşturup yapılandırırken her ne kadar küresel düşünseler dahi yerel dinamiklere de sağlam oturmanın hesaplarını yapmaktadırlar. Yerel ve ulusal kültürlere, değerlere ve yaşam pratiklerine değinildiği ve özdeşleşilmeye başlandığı taktirde başarıya ulaşmak da pek zaman almamaktadır. Yerel 
ve ulusal değer ve kültürlere hitap edilirken asıl baskın olarak egemen küresel kültür de empoze edilmektedir. Söylem, göstergeler ve imgeler ile tam bir taşıyıcılık sağlanarak hedef kitle de istendik düşünce ve davranışlar sağlanmaktadır.

\section{Egemen Küresel Hegemonya}

Hegemonya terimini modern olarak ilk kullanan kişi, İtalyan bilim insanı Antonio Gramsci' dir. İtalyan düşünür, hegemonya kavramsallaştırmasını, işçi tabanının burjuva " zengin " sınıfını, devleti ortadan kaldırmak ve işçi statüsündekilerin devletin yapısal tabakası olarak hizmet etmesinin önünü açak adına sağlanması gereken ittifaklar sistemini belirtmek için açıklarken; öte yandan, Rus işçi sınıfının köylü halk ile birlikteliğini devam ettirmesini ve kendi temel menfaatlerini sürüdüemek için, ekonomik menfaatlerini sonlandırmak zorunda olacağını belirtmek sebebi ile de kullanmıştır. Bu temelde İtalyan düşünür Gramsci hegemonya kavramsallaştırmasını, eşe değer politik geçmişe vakıf ulusal konuları kimlikselleştiren ilişkileri ve asıl olarak sosyal yapısal ilişkilerini belirtmek için kullanmıştır. Gramsci' ye göre, bir sosyal tabakanın diğer sosyal yapı üzerinde oluşturduğu etkisel durum hegemoniktir (hem rızaya/onaya hem de baskıya temellenmesi) . Başka bir ifadeyle, hegemonya Gramsci için, belirli bir sınıf ittifakının veya yalnız bir sınıfın belirli ortak menfaatlerinden sıyrılması, alt tabakaların menfaatlerinin en azından bir bölümünü kendi insiyatiflerine katmaları ve böylelikle bütün toplumun menfaatlerini savunmaları ifade edilmektedir. Bu noktada Gramsci hegemonya kavramsallaştırmasını, egemen ideolojiyi elinde bulunduran hakim sınıfın diğer yapılara yayılması ifadesiyle açılanmaktadır ve bu noktada hegemonya, ekonomik yapıdan öte kültür ve ideolojinin ön planda olduğu bir temel paradigma olarak açıklanmaktadır (Şener 2014: 1).

Dünya kapitalist düzen ve uluslararası sistem literatüründe tamamen birbirine eklemlenmiş dört temel başlık vardır;

2. 1) Uluslararası Tahakküm Olarak Hegemonya: Dünya siyaseti, Uluslararası İlişkiler (Uİ), ve Uluslararası Siyasal İktisat'ın (USİ) 
pozitivist temellerinde hegemonya, etkili tahakküm veya "hegemonizm" tarafından nitelenen egemenlik olarak açılanmaktadır. Bundan dolayı soğuk savaş dönemi boyunca Doğu Avrupa üzerinde hegemonya uygulayan Sovyet Rusya ve kapitalist dünya üzerinde hegemonya uygulayan ABD örnek olarak verilebilir.

2. 2) Devlet Hegemonyası Olarak Hegemonya: Uİ yazınının geniş kısmında ve Dünya sistemlerinde açıklanan rahat ifadeyle hegemonya, hâkim olan ulus devletin dünya kapitalist düzeninde istikrar ve güvenliği sağlaması veya ülkeler arası düzenin yürütülmesine müsaade eden uygulama ve kuralların dayatmasına dikkat çeker. Bundan dolayı kapitalizminin arka sayfalarında bir hegemonik güçler öncelikleri, örneğin Hollanda'nınkinden Britanya'nınkine ve sonrasında ABD hegemonyasına kutsal bir güç, bir "hegemonya” süregelmiştir.

2. 3) Rızaya Dayalı Tahakküm ya da İdeolojik Hegemonya: İtalyan düşünür Antonio Gramscinnin nitelikli ve öznel anlamda hegemonya ifadesi, yöneten erkine sahip bir topluluğun kendi yönetim şeklini oluşturması ve sürdürebilmesinin ifadesidir. Hegemonya kabul ile yönetim şeklidir veya sınıf idaresinin veya tahakkümünün daha da kapsamlı bir sistemin bir öznesi olarak belirli bir sınıfın, sınıf fraksiyonunun, tabaka veya toplumsal sınıfın entelektüel ve kültürel liderliğidir. Bu nitelendirmeyle burjuvazi modern kapitalist tabakalarda, dünya savaşları dönemine denk gelinse de ve hegemonik çöküş yaşasa da istikrarlı yönetin süreçleri boyunca yapı hegemonyasını sürdürmeyi sağlamıştır.

\section{4) Bir Toplumsal Formasyonun Tarihsel Bloklarının İçindeki} Liderlik Uygulaması Olarak Hegemonya: Basit ifadeyle küresel düzen noktasında üstün devlet iradesini, daha öznel ifade ile belli bir tarihsel planlam noktasında rızanın oluşumu veya ideolojik liderliği bütünleştiren bir hegemonya var oluşur. Böylelikle ABD, global siyasi iktisat noktasında ekonomik hegemonyasının ve askeri niteliğinin beslenmesinden de öte $\mathrm{ABD}$ kapitalist grubunun önderliği gölgesinde ulus ötesine varan FordistKeynesyen birikm ve bilgisinin toplumsal dinamizminin bir çıktısı olarak 2. Dünya Savaşının ardından hegemonya ortaya konulmuştur ( Robinson 2002: 2-3). 
Hegemonyanın dört kavramsallaştırmasının hepsi dünya kapitalist düzeninin gelişen tarihsel kalıplarını anlamaya katkıda bulunduğu sürece değerlidir. (Robinson 2002: 3).

Küreselleşmenin çıktılarından biri olan küresel kültür, etki alanını her geçen gün geliştirerek gelişmektedir. Şüphesiz medyanın bu noktada rolü göz ardı edilemez. Medya küreselleşme sürecinde aktif rol oynayarak, küreselleşme aktörlerinin ve medya sahipliğinin beraberliğii ile egemen kültürün diğer kültürler üzerinde birincil etkili olmasına imkân vermektedir (Taylan ve ark 2008: 2).

20. Yüzyılın sonunda küreselleşmeyle ilgili kavramsallaştırma da Robertson "evrenselciliğin tikelleşmesinin ve tikelciliğin evrenselleşmesinin iç içe eklemlenmesini ifade eden kapsamlı, çift taraflı bir süreç" olarak ifade edilmektedir. Hall' da, küreselleşme kavramını, "iç içe geçmiş tikelliklerden" ifade edilen bir çerçevede tanımlar. Robertson'daki tekelciliğin küreselleşmesi, tekliğe, ötekiliğe ve çeşitliliğe temsil edebilme imkânının sağlanmasına atıf yaparken, küreselleşmenin tekelleşmesi ise, "küresel varoluşa evrensel insani somutluk sağlama düşüncesini ifade etmektedir" (Robertson 1998: 105).

Globalleşmeyi, dünya genelinde bir sistem olarak kapitalizmin yaygınlaşmaya başlamasıyla nitelendirmek bu yapıyı bir ekonomik çerçeve olarak ele almanın yanında siyasal ve kültüre temellerini de göz önünde bulundurmaktır. Toplumlar arası adaletsiz ilişkilerin ele alındığı bu yaklaşımlarda, ekonomik hegemonyaya da dikkat çekilir. Bu açıdan, küreselleşme projesi "Batı́nın kendi dışında ki mazlum sınıflara" dayattı̆̆ 1 ve Batı burjuvazisinin emperyalist çıkarlarına destek olan bir noktaya tepki çeker" (Kızılçelik 2005: 36-37). Bu nokta da kapitalizm ile küreselleşme anı zamana tahakkuk eder. "Günümüzde küreselleşme olarak ifade edilen bu tarihsel döngü, 15. Yüzyıl da Avrupa da ortaya çıtı, 19. Yüzyılda dünyanın birçok noktasına yayıldı ve 21 . Yüzyıl itibari ile dünyayı sardı" (Kızılçelik 2004: 9). Dünyayı tek mekân ve tek kültür bütünlüğüne dönüştüren küreselleşme, "küresel köy fikri" adımlarının ifadesi olarak nitelendiren gelecek tasavvuru içinde refah ve mutlu olarak ele alan masum bu, bireysel kimlikleri aşındırıcı, planlamaların topluluk 
ruhunu yıkıcı ve parçalayıcı etkilerini ortaya çıkaran olumsuzluklar arasına bir çizgi koyar (Taylan ve ark 2008: 4).

\section{Neoliberalizm}

ABD'nin kapitalizm sistemindeki noksanlıklar 1970'lerde belirginlik kazanmıştır. İşçiler iş gücünün değersizleşmesine, çalışma temposundaki hızlanmaya ve satın alam gücünün enformasyon ile içinin boşaltılmasına isyan etmişlerdir. Bu tepkiler bütün dünyada ortaya çıkmakla beraber ABD bir taraftan Almanya ve Japonya ile rekabeti, diğer taraftan Vietnam'in savaş yükü nedeniyle bu gelişmelerden daha fazla etkilenmiştir. İşte neoliberalizm bu meydan okumalara verilen yanıttır (Gökten 2013: 166).

Neoliberalizm iktisadi ve politik bir program olup, iktisadi olarak ekonomideki devlet etkisinin azaltılmasına ve piyasa gücünün serbestleştirilmesi temellidir. Politik bir program olarak ise neoliberalizm devlet sosyalizmine ve Keynesyen refah devlete karşı duruştur (Gökten 2013: 166).

Neoliberal küreselleşme, sermayenin yapısal ve maddi gücü ile piyasa tutuculuğunun kamusal ve ideolojik olarak büyümesinden yola çıkan hegemonyadır. Bu alternatif küreselleşme, devletler ve ulus ötesi kurumlar üzerindeki etkisi olan bir güçtür. İdeolojik düzeyde neoliberal tarihsel bir blok oluşturulmuştur (Gökten 2013: 166)

Neoliberalizmin başlıca özellikleri; devletin kalkınma ve refah alanındaki müdahalelerinin azaltılması, finansal kurumlarda çarpıcı büyüme, şirket birleşmelerine ve satın almalar lehine hukuki yapılanma, merkez bankalarının bağımsızlığı ve fiyat istikrarı şeklinde sıralanabilir (Gökten 2013: 166-167).

Neoliberal hegemonya aracılığıyla sosyo politik güç ile oligopolistik piyasa yapısı arasında anlaşmayı olanaklı kılan küresel bir liderlik altında kurumsallaşma sağlanmıştır (Gökten 2013: 167).

Neoliberal düzenin yeni üretim tarzında, Fordist üretim sistemi sona ermiştir. Bilgi temelli ve iletişim teknolojisine oturan yeni bir üretim 
tarzı ortaya çıkmıştır. Bu yeni üretim şeklinin doğuşu, teknoloji ve şirketler noktasında büyük ölçüde ABD kaynaklıdır. Avrupa' da üretim de genelde geleneksel sanayi kullanılmaktadır. 1980'lerin ortalarından itibaren Avrupa’nın bütünleşme adımı, büyük ölçüde ABD ile rekabet edebilme gücünü arttırmak adına atılmıştır. Ticaret ve rekabet alanlarında kısıtlamaların kaldırıldığı bu olumsuz entegrasyonda, üretimin uluslararasılaşması, sınır ötesi merkezîleşme ve iktisadi gücün merkezileşmesi büyük ölçüde sağlanmıştır. Tarihsel olarak bu süreçte, ulusötesi " tarihsel bir blok" oluşturulmuştur. Üretim tarzındaki kayış ve yeni bloğun ortaya çıkışı, Avrupa ile ulusal kurumlar arasında yeni bir kurumsal ilişki ortaya koymuştur. (Gökten 2013: 168).

Neoliberalizmin amacı dünyaya uygun olacak bir model geliştirmek değil, aksine dünyayı modeline daha uygun dönüştürmektir. 20. Yüzyılda yaşananlara paralel bir biçimde neoliberal küreselleşmenin de çerçeveleri ve çelişkileri artmaktadır (Gökten 2013: 169).

\section{Postmodernizm}

"Postmodern", "postmodernlik" veya "postmodernizm” sözcükleri ilk defa 1930’lu yıllarda ortaya çıkmış, 1950’li dönemlerde AngloAmerikan edebiyat eleştirisinde yer almış, akabinde mimarî alanda kullanılmış, 1960 dan sonra ise de yaygınlaşmıştır. İkinci Dünya Savaşı eleştirisi ve sonrasını açıklamada kullanılan postmodernizim, sonrasında felsefî açıklamaların tanımı olmuş, akabinde bir akımın ifadesi olarak, mimari yöntemde, ekonomi de, politika ve tarihte kendine yer bulmuştur.(Çetişli 2013: 2).

Çeşitli noktalarda ifade edilmesi ve birkaç öznel kullanımlar nedeniyle postmodernizmin kavramsal olarak açıklanması zordur. Bu zorlukta postmodernizmin bir bildirimi, düzeyi ve çok olmayan bir tarihinin olmasının katkısı vardır. Bu nokta da postmodernizm açıklamalarindan bazıları:

Birçok noktaya farklılık kazandıran Postmodernizm; " insan haklarına, siyasal sistemlere, kapitalizme, ulus devlet anlayışına, tarihe, 
uzmanlaşmaya, teknolojiye karşı gelen ve sorular yöneltir. Öte yandan alt külktürlere, kültürel çokluklara, bilgeliğe, etnikliğe, yerel bilgiye, yerelliğe özgünlük tanır (Kızılçelik 1996: 128).

İkinci Dünya Savaşı ile süre gelen postendüstri ya da süper endüstri, ileri teknoloji ya da teknobilim toplumlarında ortaya konulan bir dünya görüşünü ifade eden postmodernizm, bir nesnel anlayış ve bu kapsam doğrultusunda gelişen yeni "kültürün” açıklamasıdır" (Menteşe 1999: 274).

Genel olarak batı toplumlarında ya da kapitalist kültürde yirminci yüzyılın son döneminde birçok sanat dalınd " resim, edebiyat, mimarî, vb. " ve bu sürede özellikle de sosyoloji ve felsefe de etkin hâl alan yaklaşım, akım, hareket ya da durum' dur. (Çetişli 2013: 3-4 ).

$\mathrm{Bu}$ açıklamalar göz önünde bulundurulduğunda tanımlama yapanların postmodernizm konusuna çeşitli farklı pençerelerden (sanatsal, toplumsal, eleştirel, tarihsel vb.) baktığını ya da kavramın farklı betimlemelerini (sosyal hayattaki, eleştirideki, sanattaki,) ifade edildiğini görürüz. Tüm bu yaklaşımlar, doğal olarak farklı bakış açılarını geliştirmektedir. Buna, benzer perspektif ya da görünüm temel alınmasına rağmen postmodernizm olgusunu yorumlama, anlama ve anlamlandırma farklılıkları da göz önüne aldığımızda, ne kadar yoğun bir kavramla karşılaştığımızı daha iyi anlamış oluruz. (Çetişli 2013: 4 ).

Son olarak postmodernizmin, gerçekliğin sanal dünya karşısında anlamını kaybettiği, bilginin anlamsızlaştığı, küresel dünyanın küçük bir köy olarak ifade edildiği ortamda gelişim ve büyümesini arttırd1ğını belirtelim. Bu nokta da modernizmin pek çok görüşünün yıkılmasında, DVD, CD, televizyon, internet, bilgisayar gibi teknolojilerin önlenemez ve baş döndürücü hızda gelişmelerinin payı da oldukça yüksektir (Çetişli 2013: 6).

\section{Araştırmanın Amacı}

Bu çalışma küresel ölçüde egemen olan sermaye sahiplerinin, markaların Coca Cola özelinde yerel dinamiklere de nasıl hâkim oldukları, açıldıkları pazar da ne denli bir etkiye sahip oldukları ve değersel 
yapılar ile nasıl bütünleştiklerini belirlemek amacı taşımaktadır. İzlenen teknik ile bire bir görüşmeler yapılarak kişi görüşlerini yakinen değerlendirme ve yorumlama hedefine varılmaktadır. Karşılıklı kültürel etkileşimlerin, kültürel değişmelerin ve hatta yeni kültürel yapılanmaların temeline inilmeye amaçlanmaktadır. Yapancı bir markanın ulus ötesinden, okyanus ötesinden gelip toplumların sahip oldukları dinamikler ve değersel yapılar ile nasıl bu kadar kolay ve samimi bir şekilde örtüştügü belirlenmeye çalışılmaktadır. Bu çalışma köklü yapıların, toplumsal pratiklerin ve hayat döngülerinin yapısal olarak dönüşümü tespit etme hedefine sahiptir.

\section{Araştırmanın Önemi}

Her geçen gün artan teknolojik imkânlar ile birlikte kitle iletişim araçlarının da etki ve etkinliğini artırdığ günümüzde bireyler kitle iletişim araçlarından gelen mesajlara daha yoğun maruz kalmaktadırlar. $\mathrm{Bu}$ sürekli artan mesaj trafiği içerisinde önemli bir yere sahip olan reklamların içerik ve yapısal olarak incelenmesi önem kazanmaktadır. Küresel firma ve markalar da reklam stratejisi ve mesajlarını oluştururken çok titiz ve ince bir yapılanmaya giderler. Seslenilen hedef kitlenin demografik, toplumsal, değersel ve kültürel özellikleri gibi noktaları çok iyi tespit edip mesajlar bu yönde yapılandırılmaktadır. Başarıyı yakalayanlar toplum ile özdeşleşebilmekte, satış vaatlerini gerçekleştirmekte ve daha da önemlisi kültürel dönüşüm ve düşüme etki edebilmektedirler. $\mathrm{Bu}$ araştırma bu etkiselliği fark ettirebilme ve toplumsal tepkiselliği ortaya koyma önemine sahiptir. Toplumsal hassasiyetlere değinme, etkiselliği neoliberalist ve postmodernist olarak ele alma önemine hitap eder niteliktedir.

\section{Yöntem}

Niteliksel bir araştırma yönteminin bir tekniği olan alımlama çözümlemesi, eleştiri odaklı iletişim araştırmaları kapsamında şekillenmekte, ietilerin izler-kitle ile temas anı, süreci ve ortamını ön plana koymaktadır. Bu bağlam da Stuart Hall da yetiden üretim ile beraber tüketim 
döngüsünün de süreçte yer alması gerektiğini ifade eder. Bu noktada, izleyiciler medya iletilerini tek elden okumadıklarını, bireysel ve toplumsal farklılıkların anlama ve anlamlandırma sürecinde etkisi olduğu ifade edilmektedir. Alımlama analizine önem veren kültürel çalışmalar, medya araçları vasıtasıyla üretilen anlamın izleyicinin bakış açısıyla yeniden-kurulmasına önem atfetmektedir (Demir 2012: 2).

Bu araştırmada teknik olarak alımlama analizinin seçilmesinin nedeni, yerellik ve merkeze uzaklık nedeniyle Malatya da yaşayan faklı sosyo-demografik özelliklere sahip bireylerin televizyon metinlerini anlamlandırma sürecinde farklılıklar olabileceği varsayımıdır. Çalışma da alımlama çözümlemesi yapılarak hedef kitlenin Coca Cola reklamlarında "Ramazan" konusunu nasıl alımladıklarını, hangi okuma biçimleriyle anlamlandırdıkları ortaya koymayı amaçlanarak görüşme tekniği uygulanmıştır. Katılımcıların samimi ve içten cevaplarını ifade edebilmeleri için rahat bir ortam hazırlanmış ve görüşmede önemli olan, kaynak olarak kullanılan bireylerin gerçeği söylemek için yeterince güdülenebilmesi ile istenen verilerin noksansız alınabilmesi amaçlanmıştır. Görüşme öncesinde açı uçlu sorular hazırlanmış, fakat sırasında esnasında katılımcılara duruma göre yeni yansız sorular yöneltilmiştir. Veriler ses kayıt cihazına kaydedilip daha sonra analiz için çözümlenmiştir.

Coca Cola reklamları hala devam ederek yayındadır. Fakat görüşme ve gözlemlerin olduğu zaman aralığı reklamlarda "Ramazan Ayı" konusunun üstünden 6 ay geçmiştir. Dolayısıyla görüşme soruları, 6 ay öncesinde ki reklam kampanyaları ele alınarak cevaplanmış ve çözümlenmiştir. Gözlemler de yine reklamların başlangıç ve sonu erme zamanına kadar devam edilmiştir.

\section{Bulgular}

Günümüzde televizyon reklamları her kanalda farklı konularda yayınlanarak ilgi çektiğinden ve geniş kitleleri etkisi altına aldığından, bu reklamların izleyici temelli incelenmesi gerektiği varsayımına varılmıştır. Farklı öznel konumlarda bulunan izleyicilerin her biri reklamlara 
faklı bakış açıları getirmekte hatta kendileri tekrar izlerken dahi farklı okumalar geliştirebilmektedirler. Bundan hareketle son zamanlarda popüler olan kültürel ve değersel ögeleri barındıran reklamlar arasında Türkiye'de en çok izlenen reklamlardan başında gelen Coca Cola'nın izleyicisi üzerine iletilen kodları nasıl alımlamaktadır?

\section{1. İzleyici Yorumları}

Çalışmada görüşme yapılan farklı sosyo-demografik özelliklere sahip kişilerin yorumları aşağıdaki gibidir.

- Reklam filmini izlerken ilk anda ne tür bir mesaj alıyorsunuz? D.G: Sicak, samimi ve mutlu bir aile ortamı A.B: Memleket, geniş aile

A.Ş: Bir iftar masası etrafında toplanmış aile bireyleri ve bu birliktelik Coca Cola ile sağlanmış gibi

G.T: Günün sonunda bitap ve yorgun düşmüş aile efradı ve bu yorgunluğu Coca Cola ile atmak için iftarı beklemek

D.K: Aileye yeni katılmış bir yabancı samimiyet kurmaya çalışması bu yabancı da Caca Cola

N.A: O masa da Coca Cola olmazsa iftar açılamayacakmış sanki, Fırından gelen sıcak Ramazan pidesinin tadı olmayacakmış gibi Z.Ç: Yilın en sıcak döneminde tutulan oruçlar ve akşama iftara sabırsızlıkla beklenen buz gibi içecekler ancak bu içecek cola olmamalı

M.D: herkesin Coca Cola'dan eşit pay alma çabası

İzleyici yorumlarından hareketle reklamda kültürel öğeler net bir şekilde vurgulanmakla beraber Coca Cola markasının da bir aidiyet ve vazgeçilmezlik unsuru haline geldiği net bir şekilde aktarılmıştır. Verilen ilk mesajda ailevi değerler içinde Coca Cola da harmanlanarak yabancılı̆̆ gizlenmiștir. 


\section{- Reklam da kullanılan görsel ve anlatılan metin kültür ve değer- lerimize uyuyor mu?}

D.G: Yüzeysel olarak bakıldığında uyuyor ancak derinlemesine bakıldığında bizde çok fazla masa da iftar etme Ramazan sofrasında Cola içme yoktur.

A.B: Tabi bakıldığında her insan kendine ait bir şey bulabiliyor. Küçük çocuğun firından sıcak ekmek alması eski günlerimiz anımsatıyor.

A.Ş: Uyuyor diyebiliriz. İftar sofrasına davet edilen misafirler kalabalık aile

G.T: Bizim kültür ve değerlerimiz de bütünleştirme ve kucaklama vardır. Bu görev Coca Cola’ ya atfedilmiş gibi bu yanlış.

D.K: Yok uymuyor. Çünkü cola içilmesi iftarda pek tercih edilmez

N.A: Geçmiş dönemlere ve yıllara bakarsak uyuyor, kalabalık ve birliktelik. Fakat günümüz için uymuyor diye düşünüyorum. Çünkü kalabalık şehirler de kaybolmuş çekirdek ve ufak aileler kendi yağlarında kavrulma uğraşındalar.

Z.Ç: Uyuyor. Birlik, beraberlik, samimiyet, geniş ve geleneksel aileler.

M.D: Sıradanlaştırma var. Cola sanki yıllardır hayatımızdaymış gibi bir durum söz konusu.

Her ne kadar reklam filminde toplumsal ve kültürel imgeler aktarılmış olsa da farklı toplum yapılarının ve küresel kültürel ögelerinde verilmek istenen mesajda motiflendiğini görmekteyiz.

\section{- Ramazan ayında " iftar" sofranız da Coca Cola bulunduru- yor musunuz?}

D.G: Yok. Genelde bulundurmayı.

A.B: Çoğu kez olmaz. Fakat misafir olduğunda kalabalık olunca alıyoruz tercih edenler oluyor.

A.Ş: İftar sofrasında olmaz fakat her bayram alırız misafirler için 
G.T: Bazen bulundurduğumuz oluyor.

D.K: Yok hiç tercih etmeyiz milli içeceğimiz ayran dururken

N.A: Babam kızsa da mecburen bazı günler oluyor

Z.Ç: Cola hiç tercih etmeyiz. Genelde taze sıkılmış meyve suyu veya ayran. Colanın asidi belli bir süre aç kalındıktan sonra aç aç içildi mi rahatsızlık oluşturuyor.

M.D: Bulundurmamaya çalışıyoruz. Ancak iftardan sonra bir bardak falan alıyoruz.

Cevaplar ışığında sosyal ve toplumsal olarak sahip olmadığımız bir yaşamsal pratiğin aktarıldığını görmekteyiz. Manevi olarak da eklemlenmeye çalışan marka, amacı doğrultusunda hedef kitleyi etkilemeyi amaçlamaktadır.

- Reklamlar da anlatılan konuyu düşündüğünüzde Ramazan ayında satın alma ve tüketim davranışınızda ne gibi farklılıklar oluşuyor?

D.G: Ramazan da daha az alıyorum diyebilirim. Oruç olmadığım günler yani Ramazan ayı dışında öğlen sıcağında alıyorum ama oruçken tek düşündüğüm su.

A.B: Özellikle iftara yaklaştığımda bir markette görürsem ald1ğım oluyor. İsteği bastırmak zorlaşıyor o saatlerde

A.Ş: Ben tercih etsem de çoğu kez ailem izin vermez. Ancak bayram da alırız

G.T: Çok fazla değişiklik olmuyor. Normalde Coca Colaya nasil yaklaşıyorsam Ramazan da da o kadar

D.K: Susuzluğun ve yorgunluğun bastırdığı dönemde reklamı görünce insan aramıyor değil

N.A: Ramazan ayında normalden daha çok kişi misafir ettiğimiz için alıyoruz

Z.Ç: Fark etmiyor fazla

M.D: Genelde almamaya özen gösteriyoruz. Ancak çocuklar gördü mü istiyor çoğu kez mecbur kalıp alıyoruz. 
Bu nokta da markanın tüm aile bireylerini çocuklar dahil hedef olarak kabullendiğini görmekteyiz. Coca Cola kullanma ve tüketme alışkanlığına sahip çok da sahip olmayan nispeten yaşı büyük bireyler, reklamdan etkilenen çocukların telkinleri doğrultusunda satın alma davranışı gösterme eğilimindedirler. Burada Coca Cola aile sofrasındaki ciddi bir alternatif olarak yerini almaktadır. Reklamın yayında olduğu hassas saat dilimleri (iftara yakın saatler) de hedef kitleyi satın alma davranışına iten önemli bir etken durumundadır.

- Coca Cola’nın reklamlarda anlattığı üzere kültür, değer, aile yaşantınızla ve yaşam pratiklerinizle örtüşen ve uyuşmayan yanları nelerdir?

D.G: Örtüşen yanları; masadaki birlik beraberlik ancak örtüşmeyen yanı ilk akla colanın gelmesi mesajı böyle bir şey yok

A.B: Örtüşen taraf hep beraber iftarı beklemek ancak öncelik Coca Cola değil tabi ki

A.Ş: Samimiyet, birlik evet burası tamam fakat Cola alma imkanı olmayanlarında düşünmek zorundayız

G.T: Doğudan batıya ülkenin her köşesinde aynı telaşın yaşanması güzel anlatılmış fakat ilk cola doldurulmaz masa da

D.K: Sicak günlerde oruçlu olarak emek çeken çalışan taraf var burası tamam ancak çalışan biri eve gidip bir Coca Cola içeyim diye de düşünmez

N.A: Tamamen örtüşüyor. Aile yapısı, misafirperverlik, sabır

Z.Ç: Sıcak samimi belki fakir bir aile ama elinde Coca Cola pek sanmam örtüştüğünü

M.D: Örtüşen bir taraf yok. Benim ailem önceliğini hiçbir zaman kolaya vermez ve daha yöresel ikramlar tercih edilir masamızda.

Coca Cola markasının reklam filminde vurgu yaptığı en önemli ve hassas nokta burasıdır. Tamamen kültürle özdeşleşmiş, aile yapısının sıcaklığıyla harmanlanmış ve eskilerden gelen bir tat olma kimliğine bürünme çabası içerisindedir. Toplumun her kesmini ve her zaman 
dilimini kapsayan kapsayıcı yönünü de vurgu yapılarak değersel etkileşimin arttırılması hedeflenmektedir.

- Hayatınız da Coca Cola' ya yer açma gereksinimi hissediyor musunuz? Neden?

D.G: Yok. Çünkü daha önemli önceliklerimiz var

A.B: Hayır. Cola alsam da markasına çok da dikkat etmem

A.Ş: İlla Coca Cola olacak diye özel bir çaba yok aklıma geldikçe alırım

G.T: Bir ara kola bağımlısı olmuştum. O sıralar tek içeceğim Şekersiz Coca Cola idi. Ama şu an atlattım o durumu.

D.K: Hayır. Sevmem pek diğer aile bireyleri istedikçe alıyoruz

N.A: Bazen farklılık olsun diye düşünüyor insan. Bu da toplumsal rekabetten geliyor herhalde

Z.Ç: Yer açmam. Çünkü bir yabancı gibi geliyor

M.D: Bize ait değil düşünmeyiz

Verilen cevaplar ışığında bakıldığında markanın reklam stratejisi gösteriyor ki her nokta da Ramazan Ayı gibi kıymetli bir dönemde dahi öncelikler arasına girmek ve sofrada yer açılanlar arasında ilk sıralara yerleşmek. Toplumsal statülerin ötesine geçerek modern toplum yapısına uygun satış vaadini gerçekleştirmek ve satın alma eğilimlerini arttırmak.

- Coca Cola'nın dünya genelinde bu kadar çok satmasının nedenleri sizce nelerdir?

D.G: Başarılı reklam stratejileri var. Her dilden hitap edebiliyorlar A.B: Samimiyet kurmaya başladılar. Bizden ait bir şeyler var A.Ş: Bence çok iyi bir dağıtım ağının olması. Talepleri hemen karşılayabiliyorlar.

G.T: İnsanların ne istediklerini çok iyi biliyorlar.

D.K: Müşteri, hedef kitle profilini tanıyorlar

N.A: İçinde bağımlılık yapan maddeler olduğunu düşünüyorum 
Z.Ç: Reklamları çok başarılı

M.D: Her yerde bayileri olması olabilir

Coca Cola markasının dünya genelinde bu denli satılmasında her ne kadar küresel bir firma da olsa yerel dinamiklere hâkim olması, çok iyi bir pazarlama ağına sahip olması, dağıtım ağının kusursuz örülmüş olması, her toplum yapısını ve insan profilini çok iyi analiz ederek tanımaları başarılarındaki başlıca unsurlardır.

- Coca Cola’nın bu kültürel ve değersel üretimindeki başarısının altında sizce ne gibi faktörler bulunmaktadır?

D.G: Kültürleri çok iyi tanıyorlar

A.B: Toplumsal analizleri çok iyi yapıyorlar.

A.Ş: Karakteristik özellikleri tanıyorlar

G.T: Kültürel ve değersel yolları, yumuşaklıkları iyi biliyorlar

D.K: Çok iyi bir gözlem ekiplerinin olduğunu düşünüyorum. Dinamiklere sahipler

N.A: Ellerinde tüm toplumsal veriler var ve her topluma farklı hitap etmeyi biliyorlar

Z.Ç: Teknolojik imkanları çok iyi kullanıyorlar

M.D: Kitle İletişim Araçları özellikle televizyon ile çok iyi bir taşıyıcılık sağlıyorlar

Kültürel ve değersel üretimin başarısı ve bunların gerek reklam filmlerine gerek satış vaatlerine kusursuz işleniyor olması çok iyi bir saha araştırmasının, kaliteli bir gözlem ekibine sahip olmanın, farklı toplumsal dinamiklere hakim olmanın ve hitap etme kabiliyetine sahip olmanın ve tabi ki de gerek sosyal medya gerek kitle iletişim araçlarını çok iyi kullanmalarıdır.

- Bu tür reklam filmlerinin gerçek anlamda bir kültürel taşıyıcılık yaptığını düş̧ünüyor musunuz?

D.G: Tabi. Hem bize faklı bir kültür sunuyorlar hem de gelenekten uzaklaştırıyorlar 
A.B: Evet, düșünüyorum. Farklı bir inșaa içindeler.

A.Ş: Bu taşıyıcılık sağlanmasa bu kadar küresel bir başarı da olmaz G.T: Bizi bizde iyi tanıyorlar diyebilirim. Zayıf yönlerimize göre stratejik bir plan ve taşıyıcılık içindeler.

D.K: Düşünmemek mümkün değil. Son derece başarılılar.

N.A: Kendi hayat tarzlarını yani batılı yaşam biçimlerini çok iyi yansıtırken bizden de görünmeyi başarıyorlar.

Z.Ç: Evet düşünüyorum. Yoksa bu kadar içselleştiremezdik

M.D: Hayır demeyi çok isterdim ama maalesef evet. Belki küresel anlamda bu konuda en başarılı isin marka Coca Cola

Coca Cola markası her gittiği yörede tek taraflı bir kültürel taşıyıc1lık görevi de üstlenmektedir. Orta ve Doğu toplumlarına batı yani Amerikan toplumsal yapısını taşıdığ 1 ifade edilmektedir. Küresel bir marka için bu taşıyıcılık olmazsa başarı da sağlanamaz.

\section{Sonuç}

İzleyici yorumlarından hareketle ve kavramsal açıklamalar ışığında, kültür endüstrileri ve üretimi küresel markalar için olmazsa olmaz bir öneme sahiptir. Küresel olarak dinamikleri elinde tutmak isteyen ulus ötesi markaların hemen hemen hepsi en belirgin ve başarılı olarak da Coca Cola yerel ayakları da çok iyi oturtmayı başarmıştır. Minimumdan maksimuma giden başarı yerel özdeşleşmeden geçtiği tartışma götürmez bir hal almaya başlamıştır. Rahatlayan, özgürleșen ve refaha eren toplumlar aidiyet hislerinden yavaş yavaş koparak mevcut küresel hegemonya altına girmeye başlayacaklardır. Bunu en başarılı biçimde uygulayan marka olan Coca Cola, kültürel ve değersel rahatlamaları ve yumuşamaları çok iyi görüp o yönde mesajlarını yapılandırmış, kampanya geliştirmiş ve strateji üretmiştir. Okyanus ötesi bir yabancının bu topraklarda hiç yabancılık çekmeden dolaşması, oturması bu toplumların değersel ve kültürel olarak hegonomik yapıya kapıldıklarını ve tesiri altına girdiklerini görmekteyiz. Özellikle medya okuryazarlığının 
oldukça düşük olduğu seviyelerde mesajları içselleştirmek, kabullenmek ve buna binaen satın alma ve tüketme davranışı geliştirme bir o kadar hızlı ve etkin olmaktadır. Bu nokta da sürkülasyon hızlanmış, talepler artmış ve devamında da külürel taşıyıcılık hız kazanmıştır. Toplumumuzun en önemli değerlerinden ve manevi temellerinden olan "Ramazan Ayı" nı çok iyi kullanarak ve bu konu ile bütünleşmeyi sağlayarak etkin ve başarılı olan Coca Cola, hedeflerine ulaşmıştır.

Katılımcılara yöneltilen küresel, egemen, hegemonik, kültürel ve kültürel taşıyıcılığı değerlendirme amacı taşıyan sorulara verilen cevaplar, küreselden yerele tek taraflı bir kültürel akışın ve kültürel taş1yıcılığında net bir şekilde sağlandığını ortaya koymaktadır. Coca Cola özelinde ele aldığımız çalışmada küresel şirket ve firmaların ürün nezdinde maddi ve manevi değerlerin harmanlanarak ortaya konulan kampanya ve mesaj stratejileri ile ulusal ve yerel etken ve etkinliklerini sağladıkları görülmektedir. Yapısal, kültürel ve değersel anlamda dönüşüm sağlama gayretinde olan toplumlarda, küresel firmalar için amaçların başarıya ulaşması mümkün olmaktadır.

Kitle iletişim araçlarının, medyanın, yeni medya " sosyal medyanın" birçok konuda ekin birer güç haline gelmeleriyle ve etki alanlarını her geçen gün arttırmalarıyla beraber küresel kaynaklara ve firmalara önemli bir zemin hazırlamaktadırlar. Coca Cola gibi Egemen Küresel Hegemonyanın temsilciliğini yaptığ rekse post modern toplumlarda itibarını arttırma ve iletişim kanallarını etkin bir şekilde kullanarak maddi, manevi, toplumsal, değersel ve kültürel nüfuzlarını arttırarak sürdürmektedirler.

\title{
NEOLIBERALIST AND POSTMODERN CULTURE IN SOVEREIGN GLOBAL HEGEMONY: RAMADAN IN COCA COLA ADVERTISEMENTS
}

\begin{abstract}
In this study, it is aimed to show how audiences have taken up the topic of "Ramazan in Coca Cola Advertisements", which has a significant place in today's advertising, and which is located in the advertising area that has
\end{abstract}


been spreading in recent years on television and internet environment. The dominant approach of these advertisements on the target audience is examined. In the study, qualitative research method was used. The interviews with 8 people with different socio-demographic characteristics were supported by the interview observation technique and the audience comments were taken under investigation. In the study, it was found that the viewers were very sensitive to transmission. It is among the findings that socio-demographic and cultural variables differ in terms of resistance to the content presented. It has been determined how a global brand is intensified and identified with local dynamics and values through mass media.

Key Words: Neoliberalism, Postmodernity, Reception, Sovereign Culture, Hegemony

\section{Kaynakça}

AKINER, N. \& Küngerü, A.(2012) Küresel Hegemonik İdeolojinin Popüler Tektipleştirme Pratiklerine Bir Örnek: Selfie. Erişim Tarihi: 26.11.2017

BERMAN, M. (2016). Katı Olan Herşey Buharlaşıyor (18. b.). (Ü. Altuğ, \& B. Peker, Çev.) İstanbul: İletişim Yayınları.

BÜLBÜL, K. (2007). Küreselleşme, Kültür, Medeniyet (2. b.). Ankara: Orient Yayınları.

ÇETİşLİ, İ. (2013) Batı Edebiyatında Akımlar https://www.turkedebiyati. org/modernizm_post_modernizm.html Erişim Tarihi: 25.11.2017

EKİN, C. (2011). Denizden Yükselen Küresel Hegemonya. İstanbul: Dönence Basım ve Yayın.

GÖKTEN, Y. S. (2013). Hegemonya İlişkilerinin Dünü, Bugünü ve Geleceği. Ankara: NotaBene Yayınları.

İMAMOĞLU, T. (2013). Modern Batı Düşüncesinin Felsefi Temelleri. İstanbul: İz Yayıncılık.

KENTEL, F. (2012). Yeni Bir dil Yeni Bir Toplum. İstanbul: Bilsam Yayınları. 
KIRDAR, Y. (2012). Postmodern Pazarlaam ve Tüketim Kültürü. İstanbul: Kitapsal Yayın.

LEFEBVRE, H. (2012). Gündelik Hayatın Eleştiris I. (I. Ergüden, Çev.) İstanbul: Sel Yayıncilık.

LUNDBY, K., \& Helge, R. (1991). Medya Kültürü Aracılığıyla Modernliğin Yorumlanışı. K. Lundby, \& R. Helge içinde, Medya-Kültür-İletişim (N. Gürkan, Çev., s. 4-28). İstanbul: Oslo Yayınları.

MAALOUF, A. (2016). Ölümcül Kimlikler (42. b.). (A. Bora, Çev.) İstanbul: Yapı Kredi Yayınları.

POSTMAN, N. (1994). Televizyon Öldüren Eğlence. (O. Akınhay, Çev.) İstanbul: Ayrıntı Yayınları.

ROBERTSON, R. (1999). Küreselleşme Toplum Kuramı ve Küresel Kültür. (Ü. H. Yolsal, Çev.) Ankara: Bilim Sanat Yayınları.

SERDAR, K. (2004). Küresel Medya ve Küresel Değişim. İstanbul: Naos Yayıncilik.

ŞENER, B. (2014). Uluslararası İlişkilerde Hegemonya Olgusu Ve ABD Hegemonyasının Siyasal Ve Kültürel Kaynağı: "Amerikan İstisnacılı̆̆ı" Ya Da "Açık/Kaçınılmaz Yazgı". The Journal of Academic Social Science Studies (26), 411. Erişim Tarihi: 26.11.2017

YAYLAGÜL, L. (2006). Kitle İletişim Kuramları. Ankara: Dipnot yayınları. https://www.turkedebiyati.org/modernizmi-esas-alan-anlayis-ve-postmodernizm/ Erişim Tarihi: 25.11.2017 